Mateusz DuszyK, Nina Grad

Uniwersytet Jagielloński

\title{
Rola usług i ich lokalizacji w przekształceniach społeczno-gospodarczych województwa małopolskiego po 2000 roku
}

Rozwój usług i innowacyjnej produkcji jako czynnik restrukturyzujący gospodarkę województwa małopolskiego działa w sposób zróżnicowany zarówno w ujęciu strukturalnym jak i przestrzennym. Najwyższym tempem wzrostu cechują się określone grupy działalności. Są to usługi o charakterze nowoczesnym, pełniące ważną rolę w procesie transformacji gospodarki.

Głównym celem niniejszego opracowania jest charakterystyka istotnych zmian zachodzących w strukturze przestrzennej wybranych usług w województwie małopolskim oraz określenie zespołu czynników zmian ich lokalizacji na przykładzie miasta Krakowa. Do badań wybrano lata 2004-2009. W opracowaniu posłużono się danymi Urzędu Statystycznego w Krakowie oraz branżowymi katalogami firm. Analiza katalogów pozwoliła na wyróżnienie firm i instytucji w województwie małopolskim, charakteryzujących się łatwiejszym rynkowym do nich dostępem. Realizacja celu dokonana została poprzez zadania szczegółowe: określenie dynamiki rozwoju wybranych usług w województwie małopolskim oraz określenie kierunku napływu wybranych firm w regionie miejskim Krakowa według stref rozwoju. Przedmiotem zainteresowania tego opracowania są wybrane formy usług i usług otoczenia biznesu (usługi finansowe, obsługa nieruchomości i firm) oraz usług nowych technologii.

\section{KONCEPCJE KLASYFIKACJI USŁUG}

Prace nad klasyfikacją usług rozpoczęły się już w latach 50 i 60 . XX wieku, kiedy to pojawiły się pierwsze propozycje wyodrębnienia obok sektora III dodatkowego sektora IV. Takie koncepcje zauważalne są również obecnie. D.M. Hanink (za: Kłosowski 2006) do sektora III zaliczył transport, handel hurtowy i detaliczny, administrację, usługi biznesowe oraz osobiste, a do IV - finanse, ubezpieczenia, obsługę nieruchomości, zarządzanie i sektor informacyjny. R. Bordlein (za: Kłosowski 2006) do sektora IV zaliczyła usługi finansowe, zarządy główne międzynarodowych przedsiębiorstw, pojedyncze segmenty usług dla produkcji i instytucje badawczo-rozwojowe o międzynarodowym znaczeniu. Liczne są także koncepcje podziału współczesnej gospodarki na pięć sektorów, gdzie sektor piąty określany jest jako sektor wiedzy, obejmujący medycynę, oświatę i badania naukowe. 


\section{WZROST ROLI USŁUG W GOSPODARKACH NARODOWYCH}

Usługi stanowią najbardziej znaczący sektor ekonomiczny we współczesnych gospodarkach, a ich ranga wciąż wzrasta. Są zarówno czynnikiem wzrostu gospodarczego, jak i zapewniają społeczeństwom wysoki standard życia oraz bezpieczeństwo socjalne. Do rozwoju gospodarki przyczyniają się bezpośrednio, gdyż stanowią rosnący składnik produktu krajowego brutto. W Polsce do roku 1989 polityka społeczno-gospodarcza ukierunkowana była głównie na rozwój przemysłu. Dopiero zmiany polityczne, społeczne i gospodarcze zapoczątkowane w kraju pod koniec lat 90. przyczyniły się do dynamicznego wzrostu sektora usług.

W Polsce udział usług przekroczył 60\% PKB i daje zatrudnienie ponad 55\% pracujących (Kłosiewicz-Górecka, Słomińska 2009), a sam rozwój sektora był zróżnicowany regionalnie - wysoką dynamiką cechowały się województwa z dużymi aglomeracjami miejskimi: mazowieckie, wielkopolskie i małopolskie (Dominiak 2008).

„Wzrost roli usług w gospodarkach narodowych jest elementem pewnej sekwencji rozwoju gospodarek. Jest prawidłowością ekonomiczną, która została opisana przez autorów koncepcji trzech sektorów. Prawidłowość ta polega na tym, że wraz z rozwojem gospodarczym stopniowo zmniejsza się rola sektora pierwszego (identyfikowanego przede wszystkim z rolnictwem), wzrasta, stabilizuje się, a następnie maleje rola sektora drugiego (tj. przemysłowego), jednocześnie cały czas wzrasta znaczenie sfery usług (tzw. sektora tercjalnego)” (Lechman 2009).

Usługi w dużym stopniu warunkują postęp ekonomiczny, społeczny i kulturalny, a rosnąca ranga sektora trzeciego, uważana za prawidłowość tego rozwoju, potwierdza aktualność tez zawartych w teorii trzech sektorów. Rola sfery usług w rozwoju społeczno-gospodarczym przejawia się we wpływie na dynamikę wzrostu gospodarczego, rozwój konsumpcji oraz równoważenie rynku (Okulus 1998).

\section{USŁUGI DLA PRZEDSIĘBIORSTW I OTOCZENIA BIZNESU}

Przejście z gospodarki masowej ze standardową produkcją typu fordowskiego do gospodarki nastawionej na zaspokajanie indywidualnych potrzeb klientów typu postfordowskiego, wymusiły istotne zmiany w procesie produkcyjnym o charakterze organizacyjnym, technicznym i technologicznym. By sprostać zmieniającym się wymaganiom, a jednocześnie zapewnić efektywność produkcji, rozwinęła się działalność podwykonawcza i usługi dla producentów, które pozwalają na przerzucenie części czynności wykonywanych w przedsiębiorstwie na drobnych wytwórców lub wyspecjalizowane instytucje (Zioło 1994). Jeszcze większą dynamiką rozwoju cechują się usługi dla działalności gospodarczej określane jako otoczenie biznesu (Świdurska 2007). Otoczenie biznesu, według Chojnickiego (za: Dominiak 2006, s. 7), w wąskim znaczeniu oznacza ,pewien klimat działalności gospodarczej przejawiający się w powstawaniu w regionie lub ośrodku miejskim warunków sprzyjających decyzjom lokowania i rozbudowy przedsiębiorstw, w tym także działania władz publicznych, związków zawodowych, a także kształtowanie opinii publicznej, natomiast w szerokim znaczeniu obejmuje również wyposażenie instytucjonalne oraz otoczenie innowacyjne". Przyczyn 
wzrostu znaczenia usług dla biznesu upatruje się we wzroście złożoności i konkurencyjności nowoczesnej gospodarki. Wąska specjalizacja poszczególnych dziedzin gospodarki oraz konkurencja zmusza przedsiębiorców do korzystania z usług specjalistów z dziedzin: doradztwa podatkowego i prawnego, rachunkowości, księgowości, badania rynku, reklamy, rekrutacji pracowników, prac badawczo-rozwojowych i innych (Daszkowska 1998).

\section{WOJEWÓDZTWO MAŁOPOLSKIE}

W województwie małopolskim najwyższym tempem wzrostu cechują się usługi o charakterze nowoczesnym, będące czynnikami stymulującymi rozwój społeczno-gospodarczy regionu.

Zaliczyć do nich można firmy konsultingowe ogólnie zajmujące się udzielaniem porad dotyczących produkcji, wymiany, kupna i sprzedaży towarów. W 2003 r. skupione były one głównie w Krakowie i ościennych gminach oraz w gminach powiatów zachodniej części województwa, a także w byłych miastach wojewódzkich i ich okolicy (ryc. 1). W roku 2009 rozwinęły się dotychczasowe ośrodki, ale największy wzrost liczby firm zanotowano w powiatach nowosądeckim, tatrzańskim, tarnowskim i limanowskim. Rozwój tej branży związany jest przede wszystkim ze wzrostem liczby przedsiębiorstw, dotacjami unijnymi, czyli tańszymi usługami, a wzrost w południowo-wschodniej części województwa związany jest także ze zmianą struktury zatrudnienia oraz z faktem, że miejsce rejestracji i lokalizacji takich firm nie ma większego znaczenia $\mathrm{w}$ aspekcie ich funkcjonowania rynkowego.
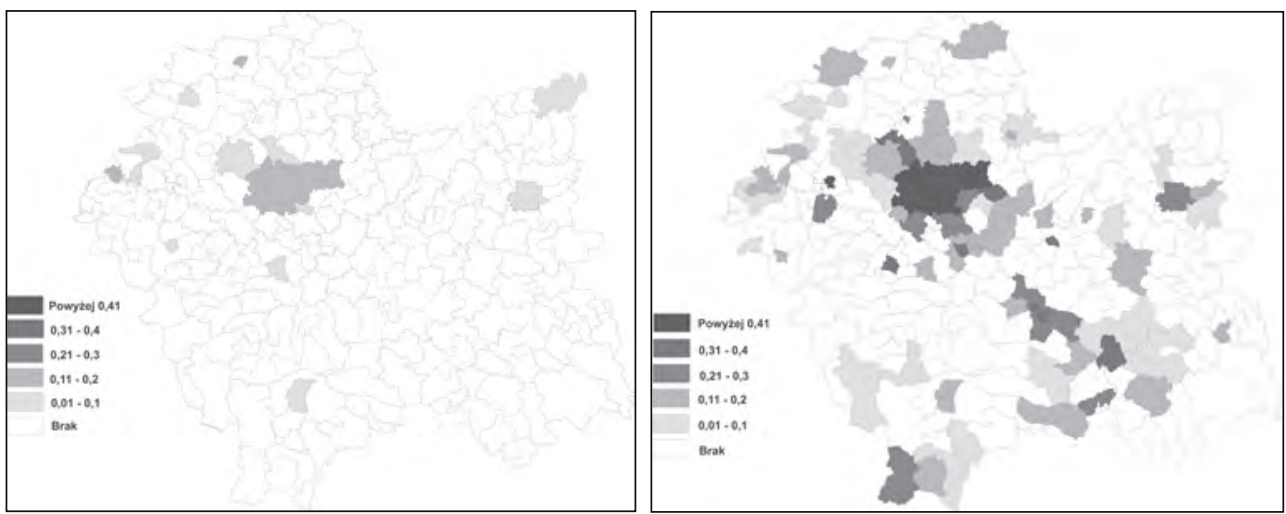

Ryc. 1. Struktura przestrzenna firm branży „firmy konsultingowe” w 2004 i 2009 r.

Źródło: opracowanie własne na podstawie Panoramy Firm woj. małopolskiego oraz Krakowskiej Książki Telefonicznej

Kolejną grupę usług reprezentują radcy prawni (ryc. 2). W 2003 r. firmy tej branży skupiały się głównie w miastach powiatowych (nie dotyczy miast i powiatów ze wschodniej i południowej okolicy Krakowa oraz byłych miastach wojewódzkich). Większa liczba radców w zachodniej części województwa wskazuje na silne oddziaływanie i zapotrzebowanie na te usługi zarówno w województwie małopolskim jak i śląskim. W 2009 r. znacznie wzrosła liczba radców w powiatach krakowskim i chrzanowskim, co podkreśla ww. 
dwubiegunowość, a w pozostałej części województwa usługi te zlokalizowane są głównie w miastach, w których w większości znajdują się sądy (Tarnów, Dąbrowa Tarnowska, Tuchów, Bochnia, Nowy Targ, Nowy Sącz, Mszana Dolna, Krynica-Zdrój, PiwnicznaZdrój).
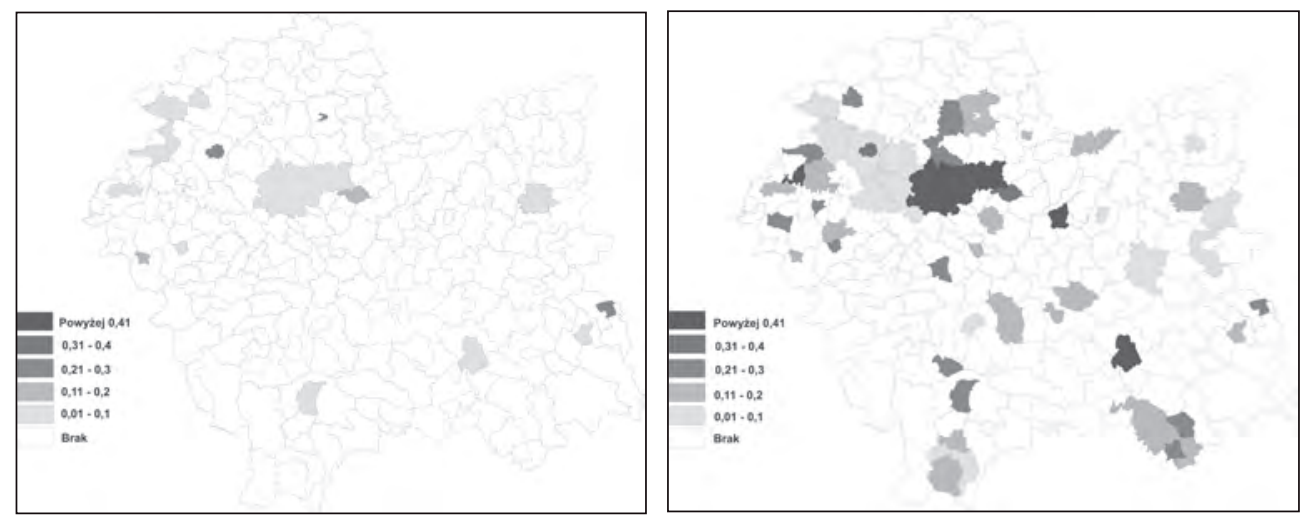

Ryc. 2. Struktura przestrzenna firm branży „radcy prawni - usługi” w 2004 i 2009 r.

Źródło: opracowanie własne na podstawie Panoramy Firm woj. małopolskiego oraz Krakowskiej Książki Telefonicznej

Trzecią grupę reprezentują firmy z branży finansowo-kredytowej (ryc. 3). W $2003 \mathrm{r}$. usługi tego typu skupione były wyłącznie w miastach powiatowych. W 2009 r. można zaobserwować bardzo duży wzrost liczby takich punktów zarówno w miastach powiatowych jak i gminach ościennych. Nagły, dynamiczny rozwój tej branży (pojawienie się wielu firm, multiagencji, pośrednictw, boom na rynku nieruchomości, wzrosty na światowych giełdach) w latach 2005-2008 spowodował bardzo duży wzrost liczby usług praktycznie na obszarze całego województwa, co świadczy również o ciągłym zapotrzebowaniu na rynku na różne usługi finansowo-kredytowe.

„Ogromne znaczenie dla rozwoju gospodarczego ma otoczenie biznesu, wśród którego znaczącą rolę odgrywają instytucje finansowe. Znaczenie tego elementu szczególnie silnie uwidacznia się obecnie podczas wychodzenia z kryzysu gospodarczego, gdzie na czoło wybija się płynność finansowa przedsiębiorstw, warunki kredytowania działalności gospodarczej, zwiększanie zasobów finansowych ludności jako ważnego czynnika aktywizującego rynek" (Zioło 2010).

Strukturę przestrzenną branży wyposażenia w sprzęt medyczny przedstawia ryc. 4. W 2003 r. firmy te skupiały się głównie w miastach powiatowych (nie dotyczy miast i powiatów ze wschodniej i południowej okolicy Krakowa oraz byłych miast wojewódzkich). Związane to było z faktem, iż w miejscach tych funkcjonowały ośrodki zdrowia, szpitale, a firmy lokalizowano w ich pobliżu. Większa liczba firm w zachodniej części województwa związana była z większą liczbą ludności oraz bliskością do miast województwa śląskiego. W roku 2009 trend został zmieniony, zauważono lukę oraz duże zapotrzebowanie na tego typu sprzęt również we wschodniej części województwa oraz w gminach uzdrowiskowych skupiających regularnie ludność przyjeżdżającą na wypoczynek lub kuracje. Przyczyniło się to do rozwoju sieci sprzedaży urządzeń medycznych w Małopolsce. Nadal jednak dotyczy ona głównie miast powiatowych oraz dużych miast, siedzib byłych województw. 

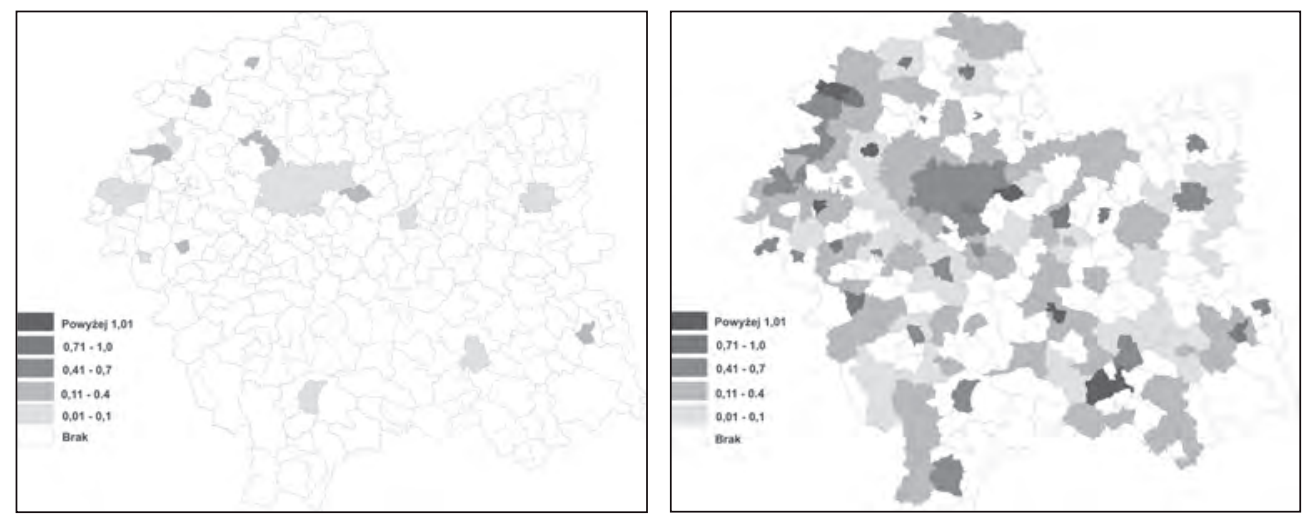

Ryc. 3. Struktura przestrzenna firm branży „finansowanie i kredyty” w 2004 i 2009 r.

Źródło: opracowanie własne na podstawie Panoramy Firm woj. małopolskiego oraz Krakowskiej Książki Telefonicznej
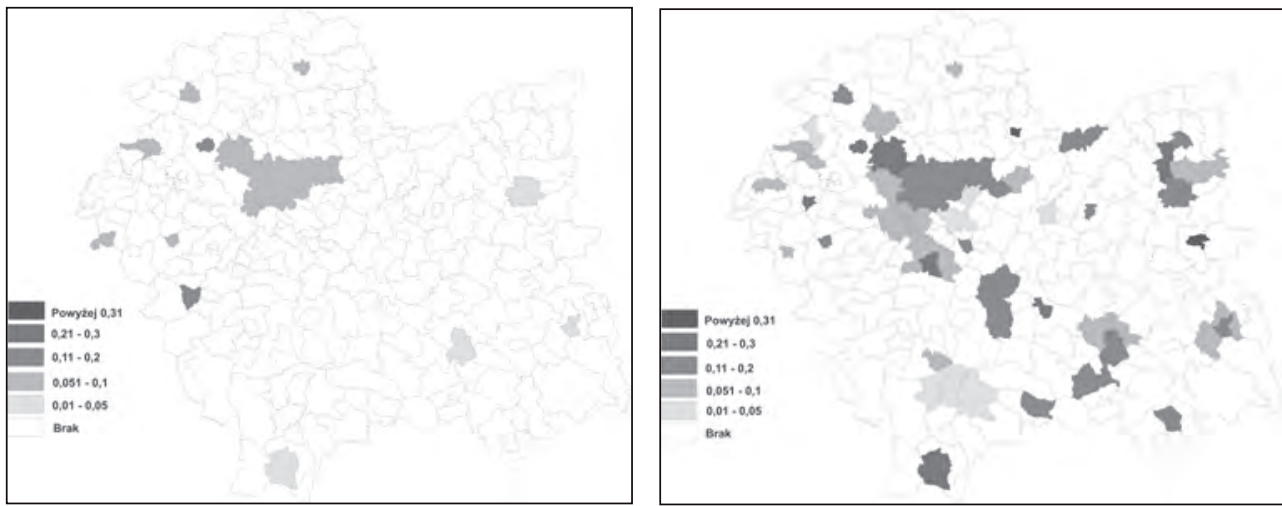

Ryc. 4. Struktura przestrzenna firm branży „sprzęt medyczny - wyposażenie” w 2004 i 2009 r.

Źródło: opracowanie własne na podstawie Panoramy Firm woj. małopolskiego oraz Krakowskiej Książki Telefonicznej

\section{REGION MIEJSKI KRAKOWA}

Region miejski przyrównuje się do układu składającego się z dwóch komplementarnych części, tj. miasta i jego otoczenia. W przypadku województwa małopolskiego obszar zakreślony granicami regionu miejskiego Krakowa, dokładniej funkcjonalnego regionu miejskiego Krakowa, obejmuje oprócz samego miasta 709 miejscowości tworzących strefę podmiejską i dojazdów do pracy (ryc. 5). 


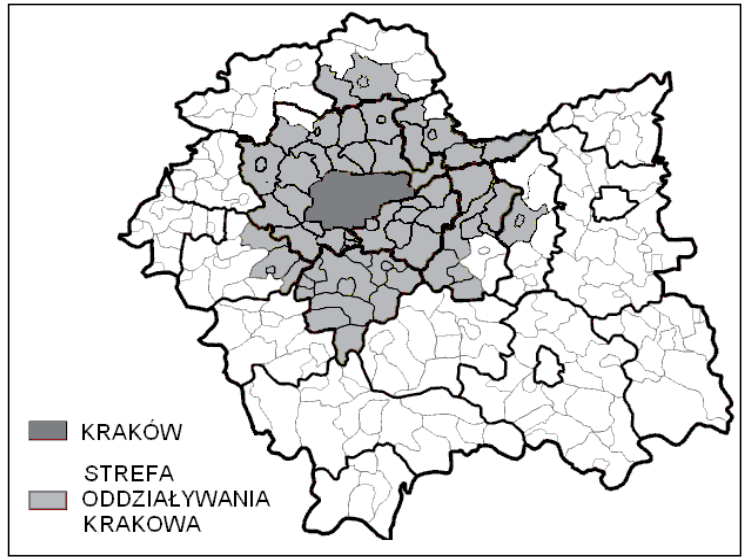

Ryc. 5. Region miejski Krakowa

Źródło: opracowanie własne na podstawie: A. Zborowski 2005

W obrębie regionu miejskiego Krakowa A. Zborowski (2005) wyróżnił dodatkowo 7 stref funkcjonalno-przestrzennych (ryc. 6). Identyfikacja samej struktury przestrzennej oparta została na złożonej procedurze doboru mierników służących do delimitacji opierających się na kryterium strukturalnym. Ogółem zastosowano 19 cech diagnostycznych, które tworzą zbiór cech demograficznych sensu stricte społecznych, morfologicznych i funkcjonalnych.

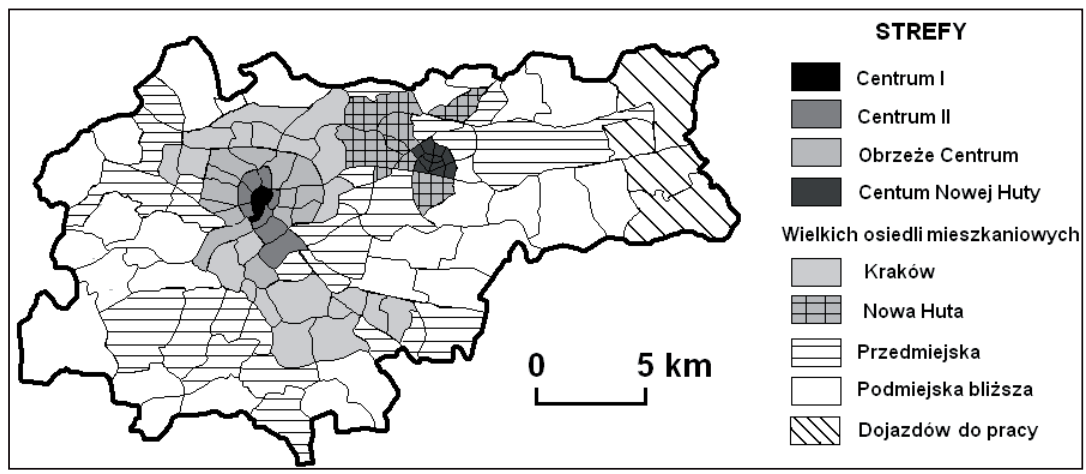

Ryc. 6. Strefy funkcjonalno-przestrzenne regionu miejskiego Krakowa w latach 1988-1998

Źródło: opracowanie własne na podstawie: A. Zborowski 2005

Przemiany struktury gospodarki Krakowa w ostatniej dekadzie w istotny sposób dotyczą usług. Kraków skupia usługową działalność gospodarczą na terenie województwa małopolskiego, a przemiany w strukturze tych działalności odpowiadają procesom nowoczesnym, konkurencyjnym i innowacyjnym. Określenie kierunków napływu wybranych firm jest ważnym elementem w analizie rozwoju usług w regionie miejskim Krakowa. Wyniki przedstawione zostały według 7 stref rozwoju (ryc. 7).

Z przeprowadzonej analizy zmiany lokalizacji firm wybranych branż wynika, że największy napływ odnotowały obrzeże centrum i obszar wielkich osiedli mieszkaniowych. 
Swoje siedziby rejestrowały tam między innymi firmy konsultingowe i otoczenia biznesu, firmy informatyczne, doradztwa prawnego, agencje nieruchomości, biura podróży. Te same działalności napływały również do centrum. Wyróżnione usługi zaliczają się do decydujących w rozwoju gospodarki miasta. Charakterystyczna była również zmiana lokalizacji w obrębie tej samej strefy. Głównym czynnikiem tych zmian była chęć funkcjonowania w atrakcyjniejszym, bardziej prestiżowym miejscu. Do bardziej oddalonych od centrum stref przeniosły się działalności związane z transportem, sprzedażą hurtową i firmy deweloperskie, czyli takie, które potrzebują większej i tańszej przestrzeni miejskiej.

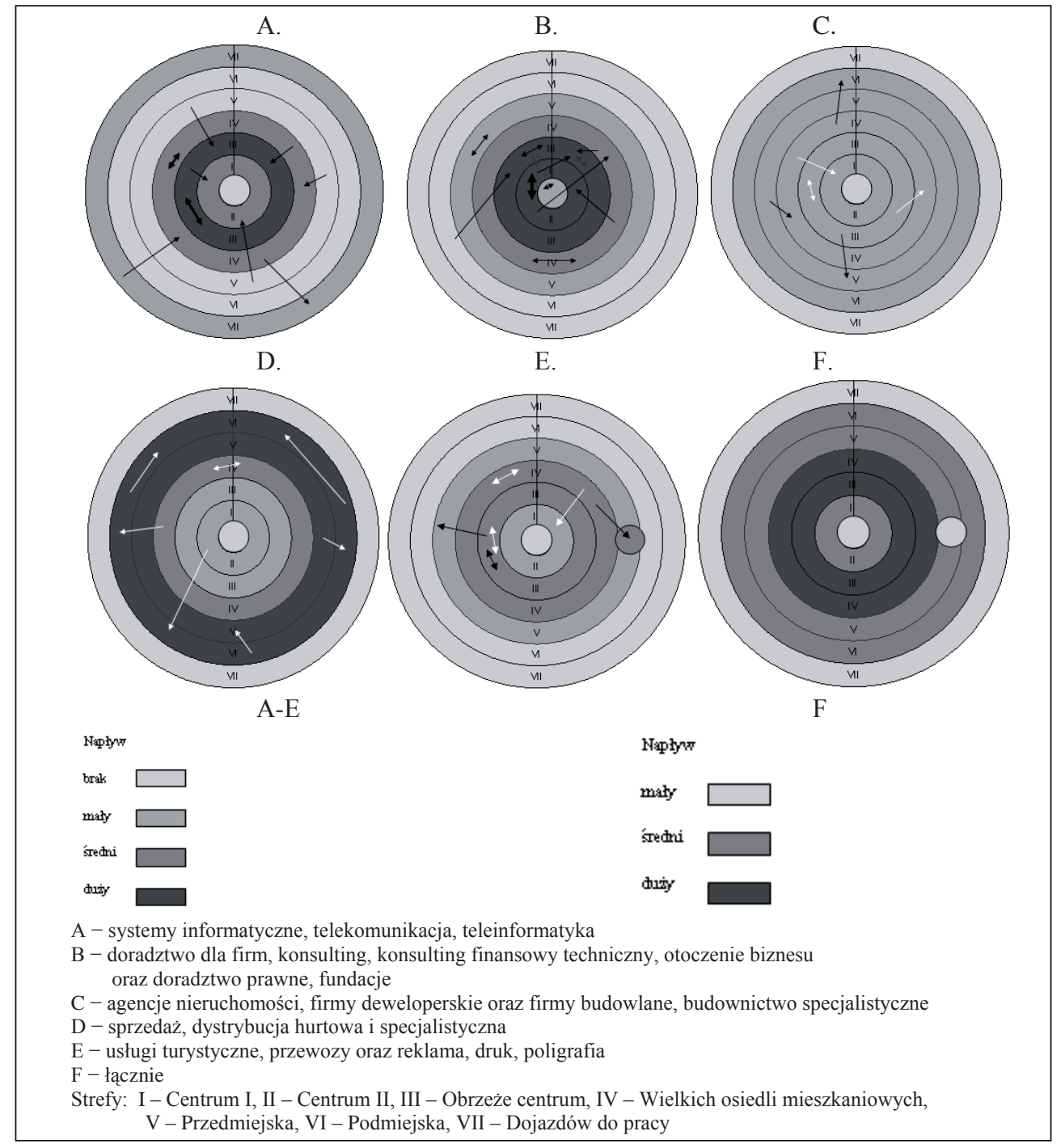

Ryc. 7. Kierunki napływu firm w regionie miejskim Krakowa według stref rozwoju w latach 2007-2009

Źródło: opracowanie własne na podstawie modelu A. Zborowskiego (2005) 


\section{Podsumowanie}

W województwie małopolskim podaż w analizowanym okresie odpowiedziała na popyt na rynku działalności gospodarczej w dwóch wymiarach: usług i produkcji oraz marketingowym. Istnieją także działalności, których „dostępność” się nie zmienia, co oznacza, że konkurencyjność wewnętrzna w regionie na wybrane rodzaje działalności jest ugruntowana pod względem produktu, ceny, promocji, dystrybucji usług i towarów. Powstają nowe działalności, które odpowiadają różnym cyklom rozwoju usług na rynku, tzn. od najsilniej zurbanizowanych stref miejskich poprzez inne obszary miejskie w regionie do regionów wiejskich. Dodatkowo szybciej odpowiedziały na zapotrzebowanie rynku gminy zachodniej części województwa oraz miasto Kraków wraz z gminami położonymi w najbliższym jego sąsiedztwie. W przypadku Krakowa widoczna jest realokacja usług charakterystyczna dla przekształceń funkcjonalnych dużych miast. Obserwowane są zmiany lokalizacji firm dokonywane według kryteriów pozaekonomicznych, opartych na subiektywnych decyzjach, co potwierdza, że sytuacja gospodarcza państwa nie zawsze ma znaczenie przy podejmowaniu decyzji lokalizacyjnych.

\section{Literatura}

Daszkowska M., 1998, Ustugi: produkcja, rynek, marketing, Wydawnictwo Naukowe PWN, Warszawa. Dominiak J., 2006, Struktura i organizacja przestrzenna otoczenia biznesu w aglomeracji poznańskiej, Bogucki Wydawnictwo Naukowe, Poznań.

Kłosiewicz-Górecka U., Słomińska B., 2009, Sektor usług w kształtowaniu rynku pracy, Instytut Badań Rynku, Konsumpcji i Koniunktur, Warszawa.

Kłosowski F., 2006, Sektor ustug $w$ gospodarce regionu tradycyjnego $w$ warunkach transformacji i restrukturyzacji - przykład konurbacji katowickiej, Wydawnictwo Uniwersytetu Śląskiego, Katowice.

Lachman E., 2009, Rozwój społeczny i gospodarczy - wybrane zagadnienia, Wydawnictwo Politechniki Gdańskiej, Gdańsk.

Okulus M., 1998, Ustugi jako czynnik aktywizujacy dlugofalowy rozwój gospodarki, Instytut Rozwoju i Studiów Strategicznych, Warszawa.

Świdurska A., 2007, Efektywność rozwoju strukturalnego matych miast w strefie wptywu aglomeracji poznańskiej, [w:] Małe miasta w obszarach metropolitalnych, red. K. Heffner, T. Marszał, Biuletyn z. 232, PAN KPZK, Warszawa, s. 8-27.

Zborowski A., 2005, Przemiany struktury społeczno-przestrzennej regionu miejskiego w okresie realnego socjalizmu i transformacji ustrojowej (na przykładzie Krakowa), IGiGP UJ, Kraków.

Zioło Z., 1994., Zmiany otoczenia przedsiębiorstw przemystowych w nowych warunkach gospodarowania, [w:] Funkcjonowanie przedsiębiorstw przemysłowych $w$ zmieniajacych się warunkach gospodarowania, red. Z. Zioło, Wydawnictwo Naukowe WSP, Kraków-Warszawa, s. 13-21.

Zioło Z., 2010, Uwarunkowania ksztattowania się procesów transformacji przemystu i ustug, [w:] Procesy transformacji przemystu $i$ ustug $w$ regionalnych $i$ krajowych uktadach przestrzennych, red. Z. Zioło, T. Rachwał, Prace Komisji Geografii Przemysłu PTG, nr 15, Wydawnictwo Naukowe UP, Kraków-Warszawa, s. 45-60. 


\section{The role of services and their location in socio-economic transformations of malopolskie voivodeship after year 2000}

Services constitute the most significant economic sector in contemporary economies and their rank is still growing. The development of services and innovative production as factor of converting the economy of małopolskie voivodeship acts in a diversified way, both in structural and spatial terms. Some particular groups of activities are marked by the highest pace of growth. They are the services of modern character, performing an important role in the process of economic transformation. The main aim of the study was to characterize the essential changes in the spatial structure of chosen services in małopolskie voivodeship as well as to determine the direction of the inflow of companies into the urban region of Cracow, according to the zones of development. The results indicate that the structure of chosen services in the center-peripheries of małopolskie voivodeship is undergoing transformations and there are some correlations between their development. In particular cases the activities are remote from the demand for them (e.g. consulting firms), which is directly connected with the use of new technologies. Cracow undergoes reallocation of services and industry which is characteristic for the functional transformations of big cities.

Mateusz Duszyk

Uniwersytet Jagielloński

e-mail: mateusz.duszyk@onet.eu

Nina Grad

Uniwersytet Jagielloński

e-mail:ninagrad@interia.pl 